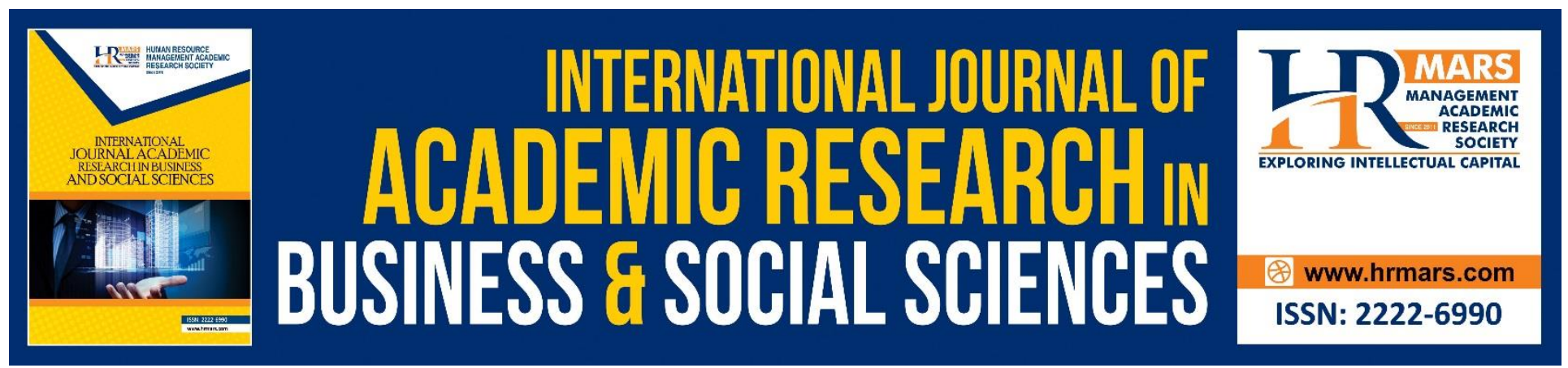

\title{
The Relationship between Food Product with the JAKIM Halal Certification and Performance of Certified Halal Food Manufacturers
}

Rizuwan Abu Karim, Nolila Mohd. Nawi, Noraznira Abd Razak, Najihah Hanisah Marmaya, Abdul Rauf Bin Ridzuan

To Link this Article: http://dx.doi.org/10.6007/IJARBSS/v8-i10/4769

DOI: $10.6007 /$ IJARBSS/v8-i10/4769

Received: 06 Sept 2018, Revised: 22 Oct 2018, Accepted: 28 Oct 2018

Published Online: 31 October 2018

In-Text Citation: (Karim, Nawi, Razak, Marmaya, \& Ridzuan, 2018)

To Cite this Article: Karim, R. A., Nawi, N. M., Razak, N. A., Marmaya, N. H., \& Ridzuan, A. R. Bin. (2018). The Relationship between Food Product with the JAKIM Halal Certification and Performance of Certified Halal Food Manufacturers. International Journal of Academic Research in Business and Social Sciences, 8(10), 629639.

Copyright: (C) 2018 The Author(s)

Published by Human Resource Management Academic Research Society (www.hrmars.com)

This article is published under the Creative Commons Attribution (CC BY 4.0) license. Anyone may reproduce, distribute, translate and create derivative works of this article (for both commercial and non-commercial purposes), subject to full attribution to the original publication and authors. The full terms of this license may be seen

at: http://creativecommons.org/licences/by/4.0/legalcode

Vol. 8, No. 10, 2018, Pg. 629 - 639

http://hrmars.com/index.php/pages/detail/IJARBSS

JOURNAL HOMEPAGE

Full Terms \& Conditions of access and use can be found at http://hrmars.com/index.php/pages/detail/publication-ethics 


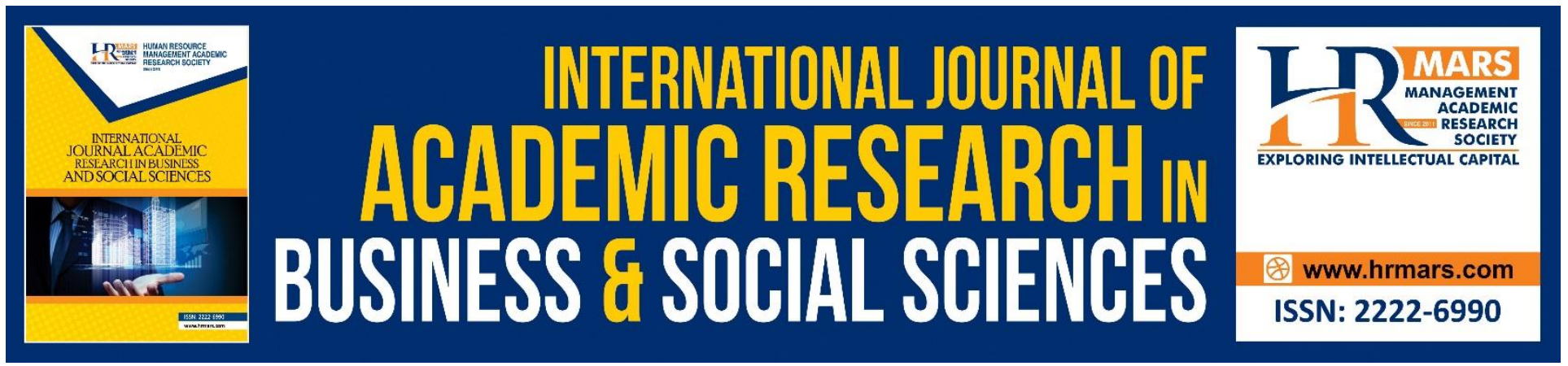

\title{
The Relationship between Food Product with the JAKIM Halal Certification and Performance of Certified Halal Food Manufacturers
}

\author{
Rizuwan Abu Karim \\ Faculty of Business and Management, Universiti Teknologi MARA Melaka, 75300 Melaka \\ Malaysia.
}

Nolila Mohd. Nawi

Faculty of Agriculture, Universiti Putra Malaysia, 43400 UPM Serdang,Selangor

Noraznira Abd Razak

Faculty of Business and Management, Universiti Teknologi MARA Melaka, 75300 Melaka Malaysia.

Najihah Hanisah Marmaya

Faculty of Business and Management, Universiti Teknologi MARA Melaka, 75300 Melaka Malaysia.

\section{Abdul Rauf Bin Ridzuan}

Faculty of Business and Management, Universiti Teknologi MARA Melaka, 75300 Melaka Malaysia.

\begin{abstract}
Due to the continuous demand and the importance of Shariah compliance of halal food to the Muslims consumers, this study examined the impact of trust and safety of food product with the JAKIM halal certification towards performance of food manufacturers. The structural equation modeling techniques (SEM) was used to examine the relationship between trust, safety and performance of food manufacturers. Data was analyzed through partial least square structural equation modelling (PLS - SEM). Meanwhile, WARP PLS version 5.0 were used for the statistical processing of the data in this study. The findings suggested that trust significantly and positively
\end{abstract}


INTERNATIONAL JOURNAL OF ACADEMIC RESEARCH IN BUSINESS AND SOCIAL SCIENCES

Vol. 8, No. 10, Oct. 2018, E-ISSN: 2222-6990 @ 2018 HRMARS

influence performance of food manufacturers. In addition, safety also were found to have positive and significant relationship with performance of food manufacturers.

Keywords: Trust, Safety, Performance Of Food Manufacturers

\section{Introduction}

The history of halal food in Malaysia started as early as 1970. In 1971, Malaysia was one of the few countries that introduced the halal logo for food products. Then, in 1980 Malaysia's legislation related to the halal issue was specified in Section 15A, Trade Description Act 1972. This act comprised two orders: Trade Description Order (the usage of halal) and food labeling 1975, which described that the food is legally fit from Shariah objective and safe to consume by Muslim consumers (Riaz \& Chaudry, 2004).

In 2004, a comprehensive guideline for Shariah standards in producing halal food has been introduced by JAKIM known as Malaysia standard MS1500:2004 (Halal Food-Production, Preparation, Handling and Storage General Guidelines). As explained in MS 1500:2004, seven basic principles that must be fulfilled by food manufacturers for the preparation of halal food such as sources of halal feed, slaughtering of animals, processing, handling and distribution, product storage, product display, product serving, safety, hygiene and sanitation practices, packaging and labelling must be in an accordance to Shariah. Another requirement under MS 1500:2004 is that food premises should avoid any cross contamination with any non-halal sources during or in between the food production process (Talib, Zailani \& Zainuddin, 2010).

Moreover in 2009, the standard had been reviewed for the second revision and was known as MS 1500:2009. Under the new requirements of MS 1500:2009, food manufacturer must recruit at least one Muslim halal executive to work at their food premises (Mohd. Janis, 2004).

Halal food does not only encompass trust attributes of Shariah compliance. But also covers the concept of safety of food as well. Trust refers to production, processing, storage and distribution of halal food products follow Shariah Law (Syed Marzuki, Hall \& Ballantine, 2012; Mohd Janis, 2004). Meanwhile, safety refers to halal food product has good hygiene practices by food manufacturers (Yaakob, Jamil, Awis Qurni \& Ahmad Nizam , 2007). Syed Marzuki et al., (2012) conducted a research to explore the attributes of halal certification among restaurant managers in Malaysia confirmed that food product with halal certification signifies trust and safety attributes.

There are several reasons why Malaysian consumers preferred to buy food products certified with the JAKIM halal certification if these were readily available in the market. First, Malaysian consumers feel more confident and have trust towards food products with the JAKIM halal certification (Rezai, Mohamed \& Shamsudin, 2012; Daud, Che Din, Bakar, Kadir \& Sapuan, 2011; Shafie \& Othman, 2006). Second, JAKIM halal certification are becoming a symbol of premium quality for food products (Syed Marzuki et al., 2012; Abdul Talib, Mohd Ali \& Jamaludin, 2008; Musa, 2008) and thirdly, the quality of products which carry the halal certification by JAKIM are similar or even better than the quality of 
food product with hazard analysis critical control point (HACCP), good manufacturing practice (GMP) or ISO 9001 certification (Daud et al., 2011; Abdul Talib et al., 2008; Shafie \& Othman, 2006).

However, the incidence of non-Shariah compliance as repoted by media massa had an impact to the performance of food manufacturers. For an example media massa reported that Cadbury chocolate (Mohamed, Abdul Rahim, Ma'ram \& Hamza, 2016) and Gardenia bread (Mohamed, Shamsudin, Rezai \& Chiew, 2008) was contained non-Shariah ingredients. This incidence had led to the Muslim consumers intention to stop buying these products. Another cases related to non-shariah compliance which had an impact to the financial performance of manufacturers was poor safety practices by Nasi Kandar Line Clear restaurant. According to the owner, he was experienced RM 10, 000.00 losses due to the unhygenic practices by restaurant staff (Sukumar, 2017. So, these incidence has raised question to the researchers about what are the impact of trust and safety attributes of food product with the JAKIM halal certification to performance of food manufacturers.

While the issue of non-Shariah compliance of halal certification is important for both Muslim consumers and certified halal food manufacturers, academic literature and research regarding a direct relationship between trust, safety and performance of food manufacturers are almost not addressed. At present, there are studies on examining a relationship between food safety system and performance of food manufacturers (Kafetzopoulos \& Gotzamani, 2014; Scott, Wilcock \& Kanetkar, 2009; Trienekens \& Zuurbier, 2008; Khatri \& Collins, 2007; Semos \& Kontogeorgos, 2007). Considering the dearth of information available, this study uses a relationship between food safety system to performance of food manufacturers as a guideline to examine the relationship between trust, safety and the performance of certified halal food manufacturers.

\section{Literature Review}

Several researchers have measured organizational performance in numerous ways. Samson and Terziovski (1999) proposed four dimensions that can be used by researchers to measure organizational performance such as financial performance, non-financial performance, innovation performance and quality performance. Meanwhile, Koh, Demirbag, Bayraktar, Tatoglu and Zaim (2007) as well as Brah, Tee and Rao (2002) measuring organizational performance based on two dimensions: operational and financial performance. Furthermore, Psomas, Pantouvakis and Kafetzopoulos (2013) and Lakhal, Pasin and Liman (2006) chosen financial performance, operational performance and product/service quality as a dimensions to measure organizational performance. However, research conducted by Ramayah, Samat and Lo (2011) showed that performance can also be measured by uni-dimension. Productivity, sales growth, financial performance, returns on investment, employee satisfaction, customer satisfaction and number of complaints are seven items measuring organizational performance. Because of the reliability and validity of organizational performance used by Ramayah et al., (2011), measurement for organizational performance in this study is similar to measurement used by Ramayah et al., (2011).

Numerous studies have demonstrated that HACCP had positive and significant effect on performance. As for the relationship between food safety system and organizational performance, Kafetzopoulos and Gotzamani (2014) investigated whether the effectiveness of ISO9001 and HACCP 
INTERNATIONAL JOURNAL OF ACADEMIC RESEARCH IN BUSINESS AND SOCIAL SCIENCES Vol. 8, No. 10, Oct. 2018, E-ISSN: 2222-6990 ㄷ 2018 HRMARS

had significant positive impact on product quality, operational performance and financial performance. Using structural equation modelling (SEM) via path analysis to test the hypotheses, results indicated that the effective implementation of both ISO9001 quality management and HACCP system in food companies had a significant positive impact on financial performance.

In the same line, some studies conducted by Scott et al., (2009), Trienekens and Zuurbier (2008), Khatri and Collins (2007) and Semos and Kontogeorgos (2007) claimed that HACCP implementations can improve the quality of food products.

Meanwhile, previous studies related to ISO 9000 implementation also showed that ISO 9000 can improve organizational performance. Studies conducted by Aggelogiannopoulos, Drosinos and Athanasopoulos (2006) examined the implementation of a quality management system according to the ISO 9000 family in a Greek small-sized winery demonstrated that ISO 9000 has a positive and significant effect on product quality.

Similarly, Naser, Karbhari and Mokhtar (2004) examined the impact of ISO 9000 registration on company performance and findings indicated there is an association between ISO 9000 registration and financial performance in Malaysian listed companies. Thus, in light of the above discussion, the researcher believes that trust and safety have a relationship on organizational performance.

\section{Conceptual Framework}

In order to examine the impact of trust and safety towards performance of certified halal food manufacturers, this study refers research conducted by Kafetzopoulos and Gotzamani (2014). Their study investigated the impact of ISO 9001 and hazard analysis critical control point (HACCP) system towards organizational performance of food firms based. The target population in their study was among food industry sector in Greek which implemented both of ISO 9001 and HACCP. A total of 840 questionnaires were sent to Greek companies in the food industry sector and only 347 food companies responded, yielding a response rate of 42.3 percent. The SEM via path analysia was conducted in their study to examine the hypotheses relationship. The findings indicated that effective implementation of the ISO 9001 and HACCP systems can influence organizational performance of companies in the Greek food industry.

Kafetzopoulus and Gotzamani (2014) work was adapted in this study is due to the fact that the quality of halal food products which carry the halal certification by JAKIM are similar or even better than the quality of food product with HACCP, GMP and ISO 9001 certification (Daud, Che Din, Bakar, Kadir \& Sapuan, 2011; Abdul Talib et al., 2008Ab; Shafie \& Othman, 2006).

Based on the empirical findings of Kafetzopoulos and Gotzamani (2014), a conceptual framework is ready to be developed in this study. The framework represents trust and safety will influence organizational performance of certified halal food manufacturers. The overall conceptual framework for this study is shown in Figure 1. 


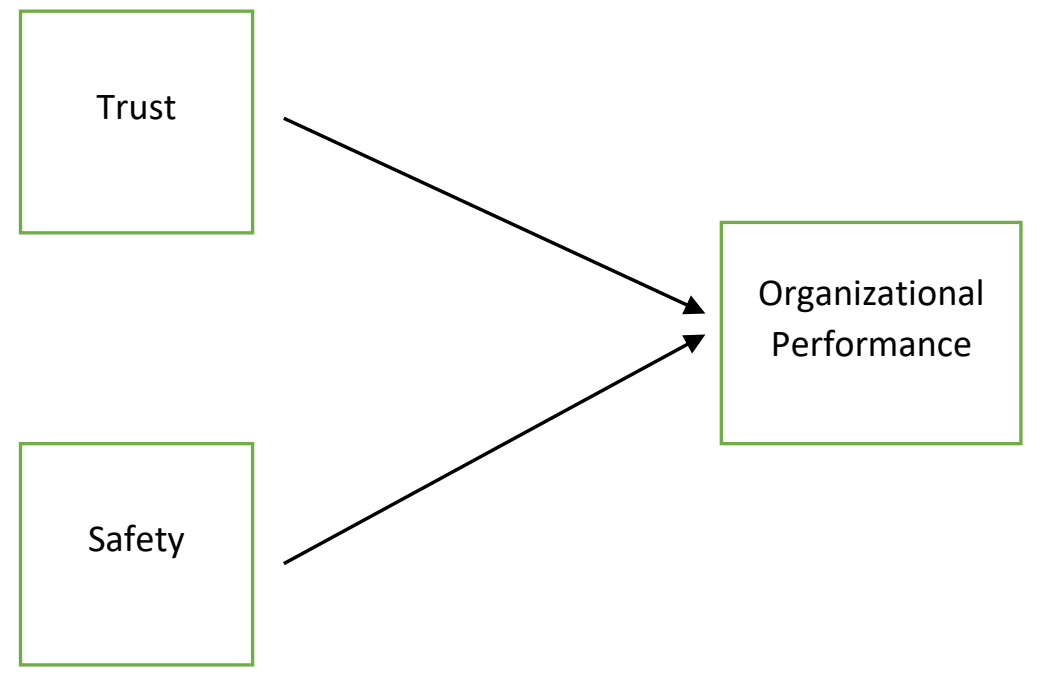

Figure 1. Conceptual framework the relationship between food product with the JAKIM Halal certification and performance of certified halal food manufacturers (Kafetzopoulos \& Gotzamani, 2014).

Based on Figure 1, there are two hypotheses to be tested in this study. Hypotheses $\mathrm{H} 1 \mathrm{test}$ direct relationships between trust and organizational performance. Furthermore, the relationship between safety to organizational performance is tested by hypothesis $\mathrm{H} 2$.

\section{Research Methodology}

A hypothesis testing will be conducted as this research is intended to recognize the relationship between trust, safety and organizational performance. To analyze the data, Structural Equation Modelling was used by using partial least square structural equation modelling (PLS - SEM). For the statistical processing of the data, the statistical analysis software SPSS 22 (Statistical Package for Social Sciences) and WARP PLS version 5.0 were used in this paper. The two step procedure approach is chosen for testing the hypothesized structural model. In the first step, assessing the measurement model is conducted, while in the second step assessing the structural model is examined.

\section{Results}

There are 200 respondents involved in this study. The majority of respondents were from the SMEs industry (157) and followed by micro business (43). Their percentage was 78.5 percent and 21.5 percent respectively. In terms of the scheme of halal certification, a total of 144 respondents (72 percent) are in the food category. Meanwhile 39 respondents (19.5 percent) are in the beverages category and only 17 respondents ( 8.5 percent) are in the food and beverages category. In relation to designation of respondents, most of the respondents were halal committee (88 respondents, 44 percent), followed by halal supervisors ( 58 respondents, 29 percent), production supervisors (51 respondents, 25.5 percent) and managers ( 3 respondents, 1.5 percent). 
INTERNATIONAL JOURNAL OF ACADEMIC RESEARCH IN BUSINESS AND SOCIAL SCIENCES Vol. 8, No. 10, Oct. 2018, E-ISSN: 2222-6990 @ 2018 HRMARS

Table 2 summarizes the results of the measurement model. Factor loading, composite reliability (CR), and variance extracted were used to assess convergent validity (Fornell and Larcker 1981). In this study, the factor loading for all items exceeded the recommended level of 0.6 (Chin, Gopal \& Salisbury 1997) and the CR ranging from 0.827 to 0.953 exceeded the recommended level of 0.7 (Gefen, Straub $\&$ Boudreau 2000). The average variance extracted (AVE) were in the range of 0.546 to 0.835 , exceeding the recommended level of 0.5 (Hair, Black, Babin \& Anderson 2010). Next, the discriminant validity was examined by comparing the correlation between constructs and square root of the variance extracted for a construct (Fornell \& Larcker 1981) and results showing discriminant validity for this study is achieved because the square root of AVE for each latent variable exceeded the interconstruct correlation. Furthermore, results of the variance inflation factor (VIF) (see Table 2) were in the range of 1.191 to 2.060, below the recommended level of 5 (Hair et al., 2010). Indicating that variables used in this paper are reliable.

TABLE 2: Results of Measurement Model

\begin{tabular}{|l|c|c|c|c|c|c|c|}
\hline \multicolumn{1}{|c|}{ Construct } & Type & $\begin{array}{c}\mathrm{N} \\
\text { items }\end{array}$ & $\begin{array}{c}\text { Factor } \\
\text { loading }\end{array}$ & CR & AVE & (Corr) $^{2}$ & VIF \\
\hline Trust & Reflective & 4 & $\begin{array}{c}0.878 \text { to } \\
0.937\end{array}$ & 0.953 & 0.835 & 0.914 & 2.060 \\
\hline Safety & Reflective & 4 & $\begin{array}{c}0.655 \text { to } \\
0.798\end{array}$ & 0.827 & 0.546 & 0.739 & 1.479 \\
\hline $\begin{array}{l}\text { Organizational } \\
\text { Performance }\end{array}$ & Reflective & 6 & $\begin{array}{c}0.690 \text { to } \\
0.907\end{array}$ & 0.931 & 0.695 & 0.833 & 1.191 \\
\hline
\end{tabular}

Structural model represents the relationship between latent variables that were hypothesized in the research model. Coefficient of determination $\left(R^{2}\right)$, predictive relevance $\left(Q^{2}\right)$, effect size $\left(f^{2}\right)$ and path coefficient $(\beta)$ are four criteria used to assess structural model in this study. The results of this study found that trust and safety seem to have a weak influence on organizational performance because $R^{2}$ value was recorded at 0.083 which means that trust and safety only accounts for 8.3 percent of organizational performance variance. According to the guidelines in assessing $R^{2}$ by Cohen (2013), the $R^{2}$ of organizational performance was considered weak.

According to Hair et al., (2010), $Q^{2}$ values larger than zero indicated that exogenous construct have predictive relevance for the endogenous construct. In this study trust, safety and organizational performance were treated as an endogenous construct. Findings showed that all endogenous constructs (where $Q^{2}$ for trust is $0.491, Q^{2}$ for safety is 0.274 and $Q^{2}$ for organizational performance is 0.085 ) have predictive relevance in this study.

Table 3 which presented the trust was found to have a positive significant relationship on organizational performance and represents a relatively small effect size $\left(\beta=0.122, p=<0.05, f^{2}=\right.$ 0.027 ). Thus, hypotheses $\mathrm{H} 1$ of this paper was supported. Next, the safety also was found to have a 
INTERNATIONAL JOURNAL OF ACADEMIC RESEARCH IN BUSINESS AND SOCIAL SCIENCES Vol. 8, No. 10, Oct. 2018, E-ISSN: 2222-6990 @ 2018 HRMARS

positive significant relationship on organizational performance with small effect size $(\beta=0.212, p=<$ $\left.0.01, f^{2}=0.057\right)$. Therefore, hypotheses $\mathrm{H} 2$ is supported.

TABLE 3: Results of Structural Mode Path coefficients, observed $\boldsymbol{p}$-value and significance level

\begin{tabular}{|l|c|c|c|c|}
\hline \multicolumn{1}{|c|}{ Path } & $\beta$ & $p-$ value & $f 2$ & Hypotheses \\
\hline $\begin{array}{l}\text { Trust } \rightarrow \text { Organizational } \\
\text { Performance }\end{array}$ & 0.122 & 0.019 & 0.027 & H1: supported \\
\hline $\begin{array}{l}\text { Safety } \rightarrow \text { Organizational } \\
\text { Performance }\end{array}$ & 0.212 & 0.001 & 0.057 & H2: supported \\
\hline
\end{tabular}

Note: ${ }^{* *}$ denotes significant at $p<0.01,{ }^{*}$ denotes significant at $p<0.05$,

\section{Discussion and Conclusion}

Findings of this paper indicated that trust had significant relationship with organizational performance. In examining the relationship between safety and organizational performance, it was found that significant positive relationship was present. The findings confirmed the proposed hypotheses in this study. In other words, trust and safety attributes of halal certification can be classified as two components which can improve performance of food manufacturers. Findings of this study consistent with prior research that affirm the significant relationship between ISO 9001 and organizational performance (Aggelogiannopoulos et al., 2006). Findings of this study also parallel with the previous findings by Khatri and Collins (2007), Loc (2006), Scott et al. (2009) as well as Trienekens and Zuurbier (2008) which these researchers concluded that food safety system can improve quality of food product. In addition, findings by Kafetzopoulos and Gotzamani (2014) further support findings of this study. Their findings stressed that implementation of hazard analysis critical control point (HACCP) and ISO 9001 can influence organizational performance.

This paper explored the above mentioned gaps and findings revealed that food product with the JAKIM halal certification can improve performance of certified halal food manufacturers. The results confirmed that halal food product which meet with the requirements of MS1500:2009 can improve performance of food manufacturers. In addition, results also were established food product which will not cause harm to the health of consumers can improve performance of food manufacturers.

\section{Corresponding Author}

Rizuwan Abu Karim, Faculty of Business and Management, Universiti Teknologi MARA Melaka, 75300 Melaka, Malaysia, Email: rizuwan305@bdrmelaka.uitm.edu.my.

\section{References}

Abdul Talib, H.H., Mohd Ali, K.A. \& Jamaludin, K.R. (2008). Quality Assurance in Halal Food Manufacturing in Malaysia: A Preliminary Study. Proceeding of International Conference on Mechanical and Manufacturing Engineering (ICME, 2008), Johor Baharu, Malaysia, 21 - 23 May. 
INTERNATIONAL JOURNAL OF ACADEMIC RESEARCH IN BUSINESS AND SOCIAL SCIENCES

Vol. 8, No. 10, Oct. 2018, E-ISSN: 2222-6990 (C) 2018 HRMARS

Aggelogiannopoulos, D., Drosinos, E.H. \& Athanasopoulos, P. (2006). Implementation of a Quality Management System (QMS) According to the ISO 9000 Family in Greek Small-Sized Winery: A Case Study. Food Control. 18(2007), 1077-1085.

Brah, S.A., Tee S.S.L. \& Rao, B.M. (2002). Relationship Between TQM and Performance of Singapore Companies. International Journal of Quality \& Reliability Management. 19(4), $356-379$.

Chin, W. W., Gopal, A., \& Salisbury, W. D. (1997). Advancing The Theory Of Adaptive Structuration: The Development Of A Scale To Measure Faithfulness Of Appropriation. Information Systems Research, 8(4), 342 - 367.

Cohen J. (2013). Statistically power analysis for the behavioural sciences ( $2^{\text {nd }}$ ed.), Hoboken.

Daud, S., Che Din, R., Bakar, S., Kadir, M.R. \& Sapuan, N.M. (2011). Implementation of MS1500:2009: A Gap Analysis. Communication of the IBIMA Journals. 2011: 1-11.

Fornell, C. \& Larcker, D. F. (1981). Evaluating Structural Equation Models with Unobservable Variables and Measurement Error. JMR, Journal of Marketing Research, 18(1), 39.

Gefen, D., Straub, D., \& Boudreau, M. C. (2000). Structural Equation Modeling And Regression: Guidelines For Research Practice. Communications of the Association for Information Systems, $4(1), 7$.

Hair, J. F., Black, W. C., Babin, B. J., \& Anderson, R. E. (2010). Multivariate data analysis. Upper Saddle River, NJ: Prentice-Hall.

Kafetzopoulos, D.P. \& Gotzamani, K.D. (2014). Critical Factors, Food Quality Management and Organizational Performance. Food Control. 40, 1-11.

Khatri, Y. \& Collins, R. (2007). Impact and Status of HACCP in the Australian Meat Industry. British Food Journal. 109(5), 343-354.

Koh, S. C. L., Demirbag, M., Bayraktar, E., Tatoglu, E., \& Zaim, S. (2007). The Impact of Supply Chain Management Practices on Performance of SMEs. Industrial Management \& Data Systems. 107(1), 103-124.

Lakhal, L., Pasin, F., \& Limam, M. (2006). Quality Management Practices and Their Impact on Performance. International Journal of Quality \& Reliability Management. 23(6), 625-646.

Mohamed, Y.H., Abdul Rahim, A.R., Ma'ram, A. \& Hamza, M.G. (2016). Halal Traceability in Enhancing Halal Integrity for Food Industry in Malaysia- A review. International Research Journal of Engineering and Technology (IRJET). 3(03), 68-74. 
INTERNATIONAL JOURNAL OF ACADEMIC RESEARCH IN BUSINESS AND SOCIAL SCIENCES

Vol. 8, No. 10, Oct. 2018, E-ISSN: 2222-6990 ㄷ 2018 HRMARS

Mohamed, Z., Shamsudin, M.N., Rezai, G. \& Chiew F.C.E. (2008). Halal Logo and Consumer's Confidence. What Are the Important Factors? Economic and Technology Management Review. 3, 37-45.

Mohd Janis, Z. Halal Food- production, preparation, handling and storage. Standard and Quality News. 2004.

Musa, N. Innovation and Competitiveness through Halal Certification. $13^{\text {th }}$ international conference on ISO9000 and TQM. Subang Kuala Lumpur. 2008.

Naser, K., Karbhari, Y. \& Mokhtar, M.Z. (2004). Impact of ISO 9000 registration on company performance: Evidence from Malaysia. Managerial Auditing Journal. 19(4), 509-516.

Noordin, N., Md Noor, N.L., Hashim, M. \& Samicho, Z. Value Chain of Halal Certification System: A Case of the Malaysia Halal industry. European and Mediterranean Conference on Information System, Crown Plaza Hotel, Izmir. 2009.

Psomas, E., Pantouvakis, A. \& Kafetzopoulos, D. (2013). The impact of ISO 9001 effectiveness on the performance of service companies. Managing Service Quality. 23(2), 149-164.

Ramayah, T., Lee, J. W. C. \& Chyaw In J.B. (2011). Network collaboration and performance in the tourism sector. Service Business. 5, 411-428.

Rezai, G, Mohamed, Z. \& Shamsudin, M.N. (2012). Assessment of consumer confidence on halal labelled manufactured food in Malaysia. Pertanika J. Soc. \& Hum. 20(1), 33-42.

Riaz M.N. \& Chaudry M.M. (2004). Halal Food Production, Florida: CRC Press, Boca Raton.

Samson, D. \& Terziovski, M. (1999). The relationship between total quality management practices and operational performance. Journal of Operations Management. 17(4), 393-409.

Scott, B. S., Wilcock, A. E. \& Kanetkar, V. (2009). A survey of structured continuous improvement programs in the Canadian food sector. Food Control. 20(3): 209-217.

Semos, A. \& Kontogeorgos, A. (2007). HACCP implementation in northern Greece food companies' perception of costs and benefits. British Food Journal. 109(1), 5-19.

Shafie, S. \& Othman, M.N. Halal Certification: An International Marketing Issues and Challenges. CTW congress. 2006. 
INTERNATIONAL JOURNAL OF ACADEMIC RESEARCH IN BUSINESS AND SOCIAL SCIENCES

Vol. 8, No. 10, Oct. 2018, E-ISSN: 2222-6990 ㄷ 2018 HRMARS

Syed Marzuki, S.Z., Hall, C.M. \& Ballantine, P.W. (2012). Restaurant manager and halal certification in Malaysia. Journal of Foodservice Business Research. 15, 195-214.

Talib, Z., Zailani, S. \& Zainuddin, Y. (2010). Conceptualizations on the dimensions for halal orientation for food manufacturers: A study in the context of Malaysia. Pakistan Journal of Social Sciences. 7(2), 56-61.

Trienekens, J. \& Zuurbier, P. (2008). Quality and safety standards in the food industry: developments and challenges. International Journal of Production Economics. 113(1), 107-22.

Yaakob, C. M., Jamil, B., Awis Qurni, S. \& Ahmad Nizam, A. Halal Hub Opprotunities. Proceeding in 4 Asian Livestock and th Feed Industry Conference, Kuala Lumpur, 25 October 2007. 